\title{
地表面下の水循環プロセスの見える化とその展望
}

\author{
嶋田 純 ${ }^{1 *}$
}

\section{Scientific visualization of sub-surface hydrological process and its horizons}

\author{
Jun SHIMADA ${ }^{1 *}$
}

\section{I 、はじめに}

地表面付近において，水は状態変化しながら太 陽エネルギーと地球の重力を駆動力として循環し ており，この水循環の個別プロセス（水循環プロ セス）の実態を把握し，地域特性を理解して当該 地域の水循環を踏まえた水利用の在り方を考究す ることが『水文学』・水文科学』の目指すところ である。 20 世紀後半から 21 世紀にかけての半世 紀は，著しい科学技術の発展と社会の要請に伴っ た，まさに『水文(科)学』発展の時代と位置付け ることができる。この水文学研究の進展を『水循 環プロセスの見える化』という観点から改めて見 直し，2018年10月に京都の総合地球環境学研究 所で開催された日本水文科学会学術大会の折に 行った会長講演をべースに，企画『水文科学(会) について語る』への投稿依頼を受けてとりまとめ を試みた。地表面より下 (土塞水や地下水) の水 循環プロセスを対象とした背景には，自身の研究 テーマと密接に関連していたこともさることなが ら，森（2017）に指摘されているように，本学 会の潮流としても主要な研究対象となっているこ とから，その動向を改めて見極める機会とできれ ばと考えている。

\section{II. 物理的・化学的観測に基づく}

\section{水循環プロセスの把握}

地下水面計を用いて井戸調査をすることで描か れた地下水面図により平面的な地下水流動が把握 できるが，ボーリング孔の深度別水圧や湧水点標 高を測定して断面方向の地下水ポテンシャル図を 描くことで，断面方向の地下水流動を把握するこ とも可能である。Fig. 1 は，熊本県宇土半島の第 3 紀火成岩山地に打ける半島稜線部から沿岸部扎 よびその先の八代海海底下まで連続している角磁 凝兏岩系帯水層に打ける地下水流動を把握するた めに作成した複数のボーリング孔の深度別水圧や 涌水湧出点等の情報を基に描かれた断面方向の地 下水ポテンシャル図である。このような岩盤内に おいても，いわゆる地域流動系の地下水流動が存 在していることが明確に示されると共に，このよ うにして把握された地下水流は，安定同位体比の 高度効果特性を利用して推測される涵養標高を基 にした地下水流れや年齢トレーサー分布とも極め てよく整合することが確認されている（Shimada et al., 2007; 辻村，2008)。多孔質带水層に打い ても，2016年の熊本地震で枯渴した水前寺成趣 園池と地下水の関係を見極めるべく Fig. 2 に示す ような断面 2 次元のポテンシャル分布を作成して 地震前後の地下水状況を比較した。この判読の結 果，水前寺成趣園のある詫麻台地中央部に地震に 伴って新たに出現した断裂系への地下水の吸い込

1 熊本大学名誉教授. 大学院先導機構特任教授 Prof. Emer., Kumamoto Univ.

* 責任著者 
(a)

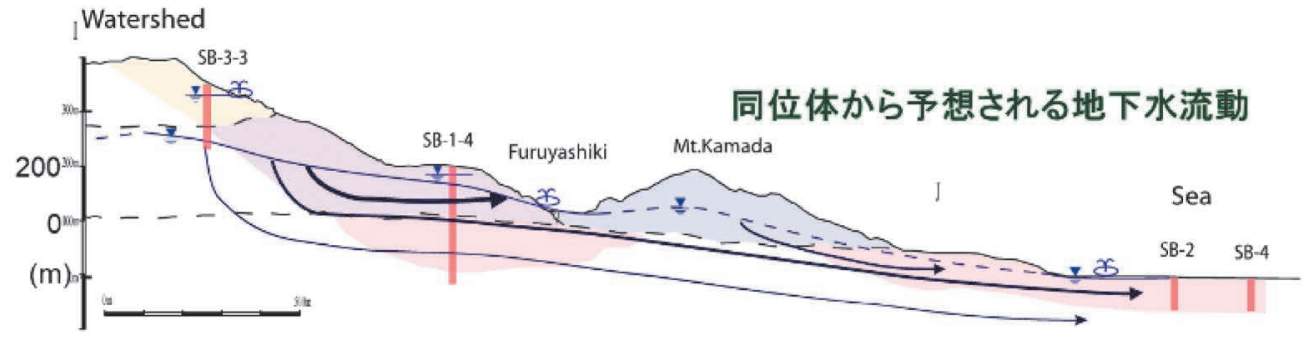

(b)

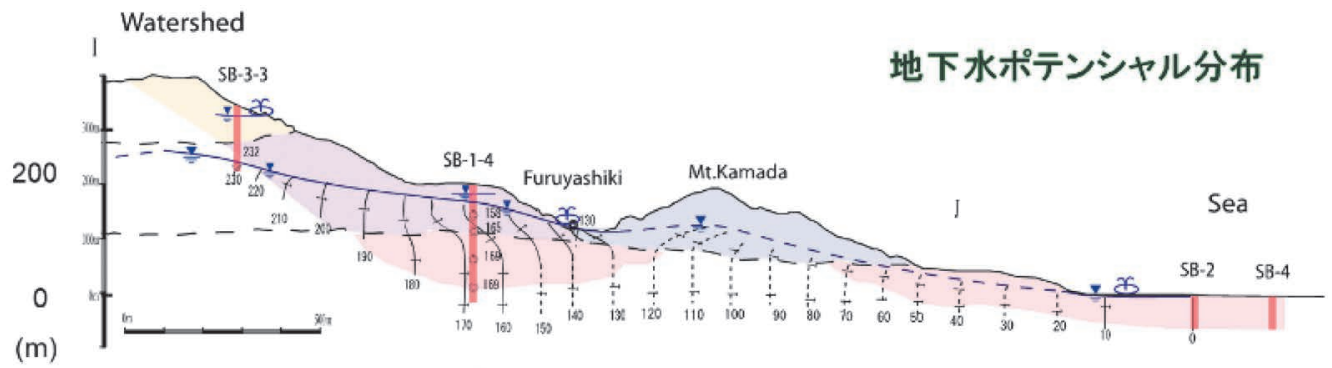

16 years

(c)

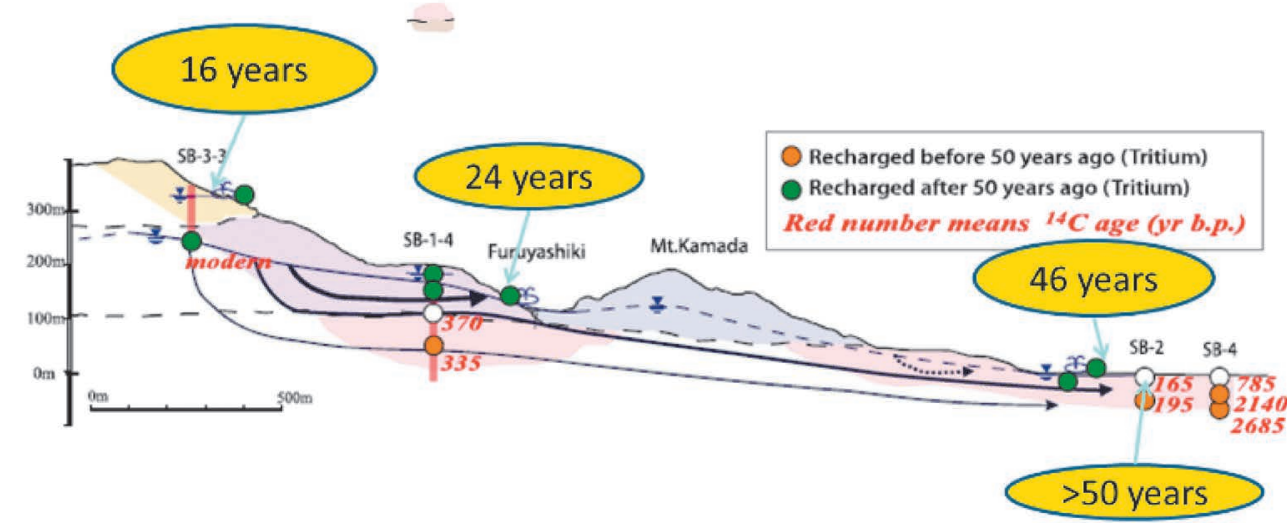

Fig. 1 Groundwater flow system confirmed by (a) stable oxygen isotopes, (b) the potential distribution and (c) age tracers at Shiranui tuff-breccia aquifer watershed of Uto Peninsula (Groundwater age shown in the yellow ovals was confirmed by CFCs, Shimada et al., 2007 and Tsujimura, 2008) .

み現象に伴う水位低下が湧水池枯渇の原因である ことが明らかとなった。

土壌の比抵抗值は，その中に含まれる水分量に よって変化するため，同じ測線で比抵抗值を繰り 返し測定し，その変化量を時系列比較することで 蒸発や浸透に伴う土壤水の動きをとらえることが できる。Fig. 3は，九州沖縄農業センターの広葉 樹林内に設けた $50 \mathrm{~m}$ の測線沿いに, $50 \mathrm{~cm}$ 間隔で 設置した約 100 本の電極を用いて 6 時間毎の繰り 返し電気探査を約 2 年間に渡り実施し, 深度 $13 \mathrm{~m}$ までの土壤の水分量観測を行った研究成果である
(嶋田ほか, 2008)。観測された比抵抗值プロファ イルの変化量から換算された水分量変化から，樹 木の存在している場所と裸地とでは異なる土䁃水 分の季節変化が存在することを確認すると共に, 樹幹直下では降雨に伴う樹幹流による水分量増加 の影響を明確にとらえている。地表面での水収支 を考えた場合，樹木は蒸散として水を消費するマ イナス要因であるが，一方，樹幹流による積極的 な水の捕捉作用も存在していることが分かる。

また，塩水と淡水で比抵抗が大きく異なる特性 を利用すると，潮汋変化の激しい干潟部に設置し 


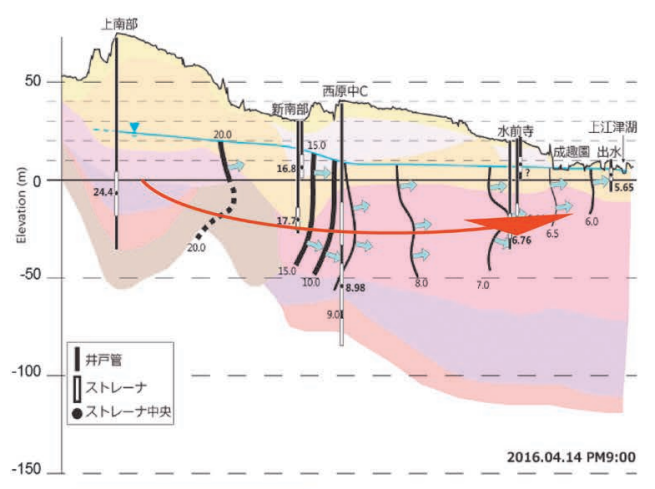

施霹能
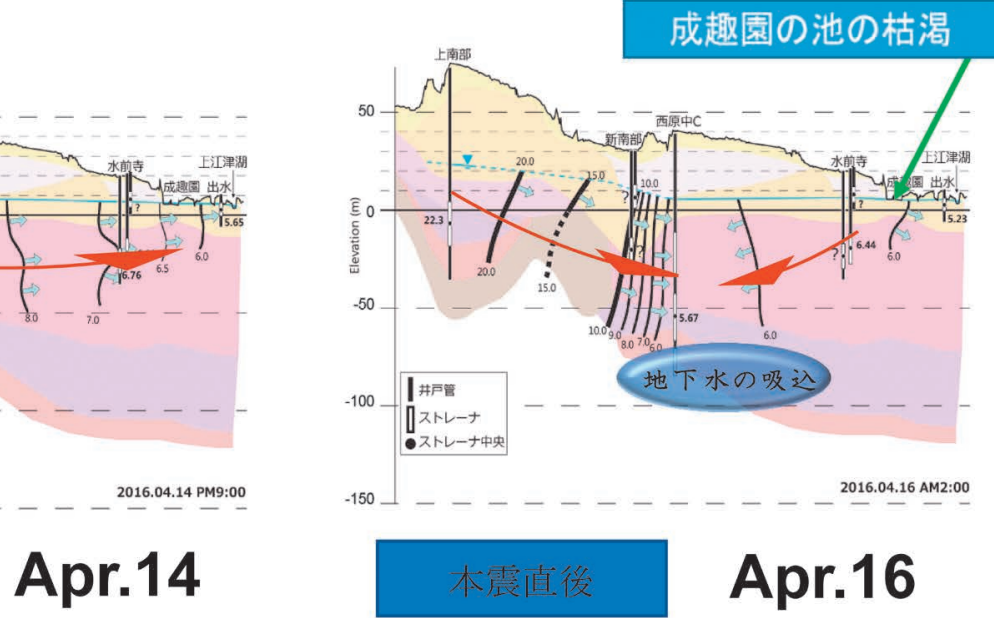

\section{Apr.16}

Fig. 2 Change of groundwater flow system before and after Kumamoto Earthquake 2016 (Shimada, 2018).

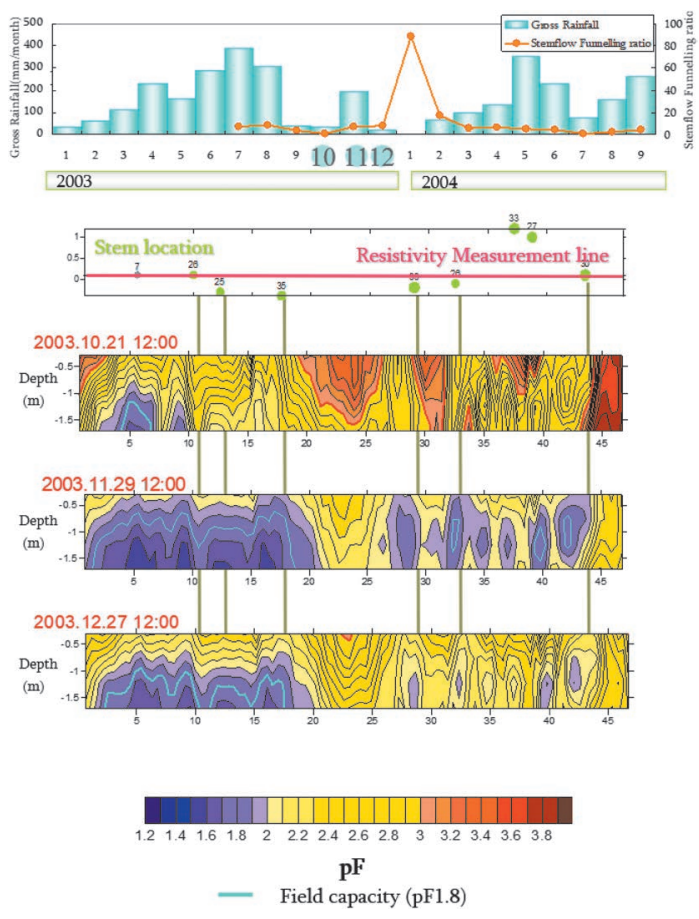

Fig. 3 Change of cross-sectional soil water content confirmed by repeated resistivity measurement (Shimada et al., 2008).

た測線による同様の比抵抗繰り返し測定によって, 沿岸域における潮汐変化に伴う塩淡境界の変化を 明確にとらえることにも成功している (Fig. 4; Shimada et al., 2007)。沿岸部の海底地下水湧出

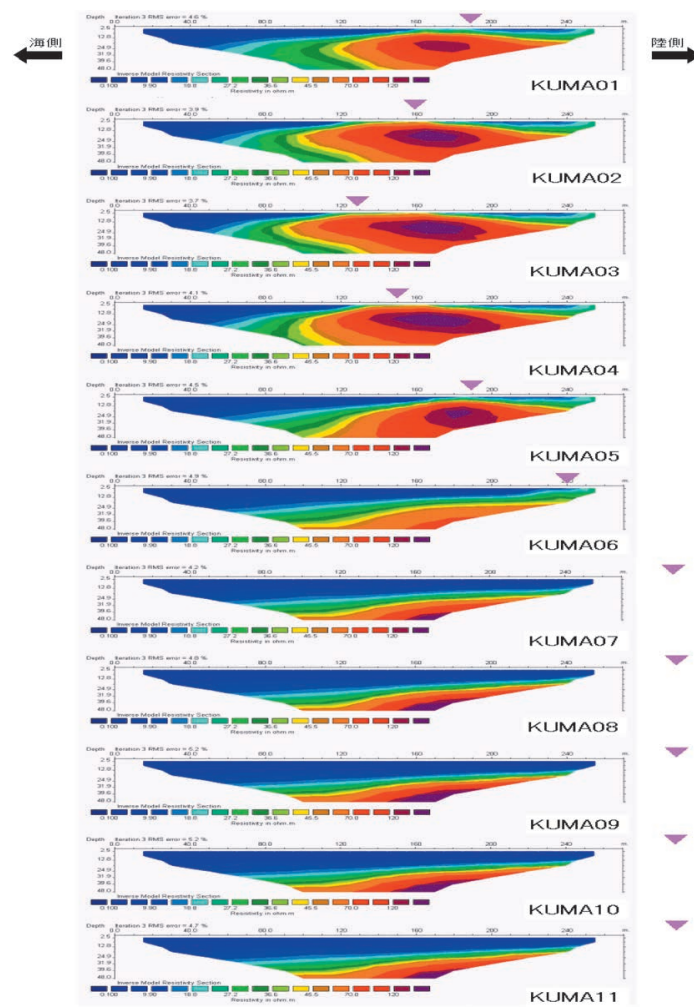

Fig. 4 Change of repeated resistivity profile under the tidal flat area to confirm the submarine groundwater discharge during tidal fluctuation (reddish color represents fresh groundwater and bluish color represents sea water, pink triangle indicates the location of coat line, Shimada et al., 2007). 
現象は，淡水地下水の持つ地下水ポテンシャル (その背後に存在する地下水流動構造が影響）と， 湧出部の上部を覆う海水水圧の変動に伴ってその 湧出量が制御されている。

\section{III. コンピュータシミュレーションの活用}

大気の動きが観測データと過去の記録を基にか なりの精度でコンピュータシミュレーションに よって再現できるようになり，台風の進路や局地 的豪雨予測はともかくも，通常の天気予報精度が 格段と良くなってきたことで分かるように，水文 循環場（特に地下水循環）に扔いても，的確な情 報が提供されることにより，シミュレーション解 析で再現する手法が広く利用されるようになって きている。地表を流れる河川水と地下部分に浸 透・流動する土䁃水・地下水を統合的にモデル化 する解析技術は, 降水量と気温を入力データとし て河川流量や地下水位の観測值の再現性を向上さ せることで，地下部分の水の流れの実態を再現す
ることができる。加えて当該地域で得られた保存 性の高い環境トレーサー観測履歴を同時にヒスト リーマッチングに用いることができれば，流域の 地下水流れをより正確に同定できる（嶋田・上野, 2016)。このような優れた流域地下水流動モデル が構築できると，それを利用して土地利用が変化 した場合の地下水流動場の変化を掌握することが 可能となり，地下水管理政策への積極的な利用に つながる素地を持っている。例えばFig. 5 は，熊 本地域で取り組まれた休耕田を利用した地下水人 工涵養事業の効果を確認するために，白川中流域 低地の土地利用が異なる 4 つの時代を対象にして， 土地利用の違いが涵養機能にどのように影響する かを比較したものである (Shimada et al., 2012)。 結果的に水田あるいは休耕田水張事業が地域の地 下水涵養に相応の効果を果たしていることが，相 対的に大きな涵養量分布域として明示されてい る。2004年以降熊本市が中心となって組織的に 地域で取り組み，国連の受賞までに至った休耕田 水張事業の開始時にはまだ当該モデルが存在して
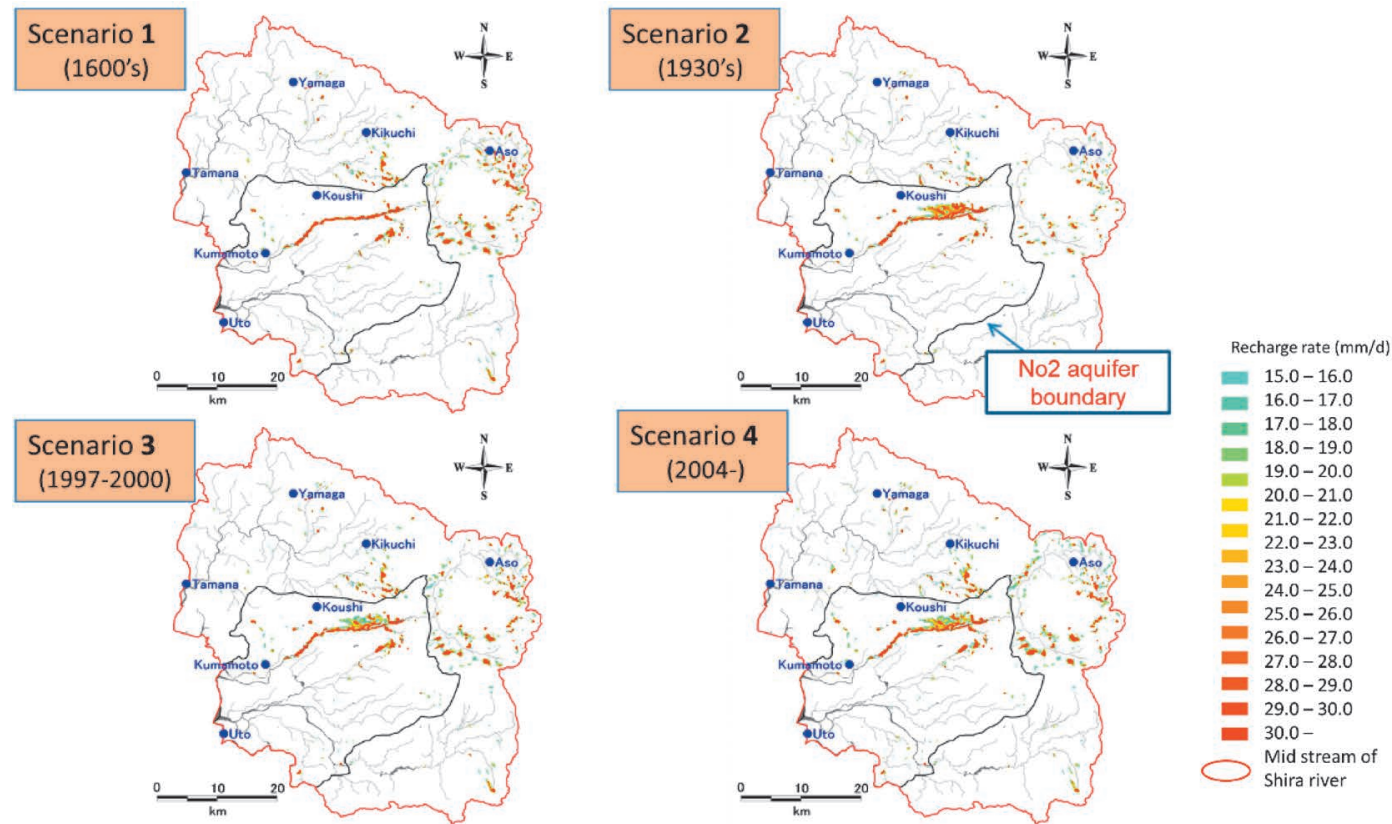

Fig. 5 Effect of artificial groundwater recharge through abandoned rice paddies in Mid-stream area of Shira river, Kumamoto, confirmed by groundwater flow simulation for different land use scenario (Shimada et al., 2012). 
いなかったため，それまでの経験知を基に地域の $\mathrm{NPO}$ と進出企業とが地下水保全策の一環として 取り組み始めた事業であったが，今後他の地域で 類似した事業に取り組む場合には，地域の地下水 流動モデルを活用して水理地質学的適地を的確に 選定して事業に取り組むことで，より効率の良い 事業運営を可能にし得ると考えている。

Ide et al. (2018) は，霧島火山の滞留時間の異 なる裾野涌水における地下水年代や涵養標高デー 夕を基に, 地下水流動に伴う化学的風化プロセス に時間軸を入れた解釈をすることに成功しており， また Nakaya et al. (2018) では, 琉球石灰岩中 に設けた地下ダムによる地下水滞留の程度差が, 地下水中の硝酸態窒素の変遷プロセスに影響を与 えていることを指摘している。このように明らか になりつつある流動に伴う非保存性の化学物質 $\left(\mathrm{SiO}_{2}\right.$ や $\mathrm{NO}_{3}-\mathrm{N}$ 等 $)$ の帯水層中での振舞いにつ いても, 地下水流動モデルの中で帯水層中に打け る変遷プロセスとして的確にモデル化できれば, その結果を利用することで硝酸態窒素のような污 染物質の削減対策の構築やその是非を評価する ッールとしても活用できる可能性を秘めている (嶋田・上野，2016)。

現在我々が接している水循環場には，様々な時 間スケールで流動している水が存在しており, 調 查現場から採取した地下水や間隙水の中には, 現 世とは異なる環境下で捕捉された水が残存してい ることも十分想定される。Fig. 1の一番下に示し た宇土半島に打ける地下水年代分布四を見ると図 の右側部分（現在の八代海の海底下 $50 \mathrm{~m}$ ）には, 炭素 14年代で 2100-2600年前に相当する古い淡 水性地下水の存在が示されている。この部分は, 同罒の左側に示されている角碩凝灰岩山地域の数 十年から百年程度のオーダーの現世水循環とは全 く異なる時間スケールの滞留性地下水と見られ， 現在の海底下にある海成粘土層の堆積年代とほぼ 一致していることから, 恐らく2000年前頃の八 代海の海進に伴って海底下に封入された水循環系 だと解釈している。類似した過去の水循環場履歴 の封じ込め現象は, より堆積速度の速い霞ケ浦の
湖底堆積物中のコア間隙水でも確認され，コア間 隙水の化学成分には場所による差異が大きいこと が指摘されている。すなわち, 霞ケ浦地域が陸化 したことで形成された淡水性地下水による海成成 分の洗い流しの効果が顕著な場所とそうではない 場所が存在していることが, 湖内 2 か所の底質コ アサンプルの間隙水プロファイルを用いた安定同 位体と塩素イオン濃度情報から明らかにされた (高本ほか，2016）。霞ケ浦周辺地域におけるこ れらの完新世から現在に至る水文環境の変遷を説 明するために, 過去の海水準変化, 堆積速度, 隆 起・沈降情報等の水文環境推定值をべースにした 非定常地下水流動解析を実施することで，地下水 流動モデルから湖底堆積物中のコア間隙水質観測 データの再現を試みた結果，過去 1 万年スケール の水文環境変遷がコア観測に基づく解析結果と相 応に整合していることが確認され, 当該地域の古 水文環境の変遷を明らかにすることに成功してい る (高本ほか, 2017)。Fig. 6はその結果である が，湖心に近いK-2 と出島半島に近いK-1とで は, 陸域からの距離が異なるため, 海成層堆積時 に混入していた海水成分（黄から赤の暖色系）が 7300 年前から現在に至る間に受けた陸化に伴う 湖周辺の陸域部から湖に向かう淡水性地下水流動 によって希釈される効果に違いをもたらしている 様相（K-1の方がより多く希釈されている）が読 み取れる。

2016 年 4 月, 熊本地域は $\mathrm{M}_{\mathrm{j}}=7.3$ 規模の大きな 内陸型地震に襲われ，その後 1 年近く続いた 1 万 回近い余震と共に，地域に甚大な被害がもたらさ れた。地下水を水道水源として利用している関係 から，地域には 30 年以上の観測実績のある 100 本 以上の地下水観測井戸があるため, 地震前後の期 間に対してこれらの地下水位観測結果を詳細に解 析することで, 地震に伴う地下の変動が地下水帯 水層や地下水流動にどのような影響を与えたのか を解明することが可能である。Fig. 2 に示したよ うな断面地下水ポテンシャル図による現象把握に 加えて, 地下水温・環境同位体トレーサー等につ いて地震前後の変化を確認すると共に，それらの 

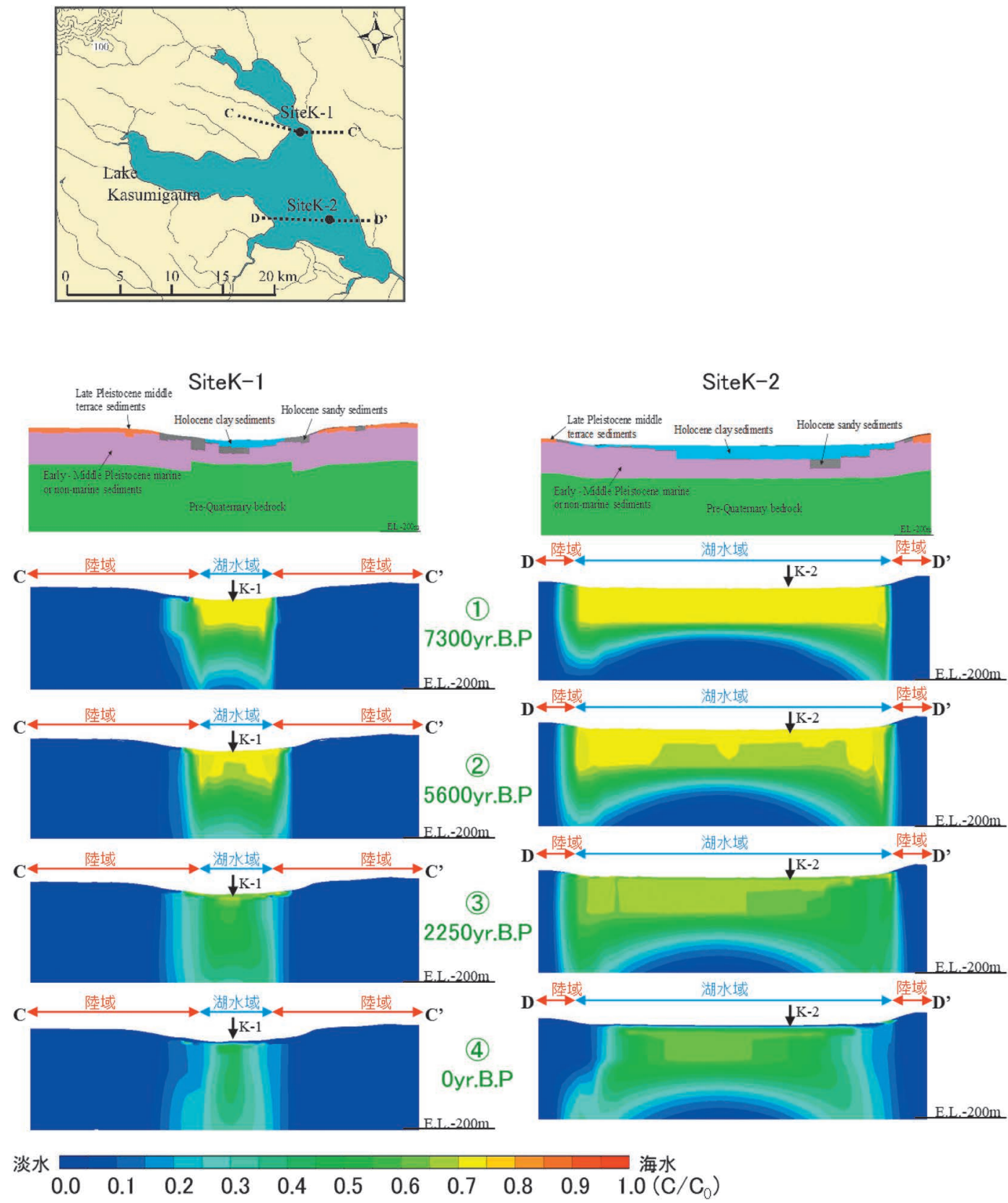

Fig. 6 Temporal variation of the simulated salinity distribution around Lake Kasumigaura in last 10000 years validated by the lake bottom soil water chemical information (Takamoto et al., 2017).

変化を説明することができるように，既に確立さ れている地域の地下水流動を再現できている流動 シミュレーションモデルに地震に伴う地殼の変化 を組み込むことで, 地震時に出現した地域の水循 環変化に係る現象の科学的解明に現在取り組んで
いる。例えばFig. 2のような新たに出現した断裂 系への地下水の吸い込久現象についても, 基盤部 に新たに出現させた亀裂系に吸い込まれた地下水 量が帯水層の地下水低下量と十分バランスできる ことが，新たに構築した基盤部の新規亀裂迄含む 
ようなモデルによって示されてきている（細野ほ か, 2018)。

\section{N. おわりに}

概念として理解されていた水循環プロセスにつ いて, 20 世紀後半に発達してきた様々な手法を活 用することで，『水循環プロセスの見える化』が 可能になってきた事例を紹介してきた。地表面下 の水の動きを再現できるモデルは, これまでの観 測水文学から得られたデータを基に, 現実に起こっ ている地表面下の水循環プロセスを再現できるレ ベルにまで到達してきている。地表付近の水の循 環様式は地域性が極めて高いが，それらを適確に 把握するッールを活用することで，我が国のよう な温帯湿潤地域ではその循環様式を踏まえた水資 源利用を行うことでその持続的利用を可能にでき る。

農林業センサスによれば，わが国の戦後 60 年間 の農家数と農業従事者数の推移は, 農家数が 604 万 戸から 133 万戸へ, 農業従事者数が 1932 万人から 340 万人へ大きく減少している。さらに 1960 年 当時 60 歳以上の高齢農家の比率は 2 割程度だっ たが，現在では 70 歳以上が約半分の $47 \%, 60$ 歳 以上が約 8 割の $77 \%$ を占めて打り著しい高齢化が 起こっている（山下，2016）。このような流れの 中でも食料自給率を確保できるようにこれからの 農業を維持してゆくためには，より効率を高めた 大規模集約化農業の導入は避けられない。一方, 湿潤地域の水循環に大きく影響を及ぼす水田農業 や地下水資源への窒素負荷の要因となる畑作農 地・畜産地域を流域内の適正な場所に再配置する ような形で大規模集約化農業の導入ができれば, 水利用政策と土地利用政策とをリンクさせた地域 経済と環境の双方にやさしい持続的農業・持続的 水利用を確保することが可能である。このような 農業・水資源・環境の相互関連性を踏まえた新た な抜本的政策の展開が, 総人口が低下してきたこ れからのわが国にとっての重要な課題である。

全球温暖化に伴う降水の極端化現象の頻発に
よって河川流量の不安定性が増大しており，それ に対する抜本的対策は極女て難しい。一方地下水 資源は，その貯留特性によりこれらの降水変動に 対する脆弱性が相対的に低く，その特性を生かし て湿潤温帯の恵まれた水循環特性を十二分に活用 した地表水と地下水の統合的水資源利用を確立す ることが強く求められており, その中で水文学の 果たす役割は極めて高い。『水循環プロセスの見 える化』の先にあるものは，これらの技術を地域 水資源の持続的利用に積極的に活用することにあ ると考えている。今年度から学会 HP上で公開さ れた本誌の前身誌『ハイドロロジー』の創刊号巻 頭言では，水文学を庶民の学問と位置付け，『庶 民の学問は必要がその存在を保証し, 発達を要請 する』（山本，1967）と述べている。これからの 我が国に打ける持続的な水資源利用にとって『水 文学』は不可欠である。

\section{文献}

嶋田 純·大角京子·大場和彦·丸山篤志 (2008) 比抵抗探查法を用いた広葉樹林床土潩における 樹幹流の影響把握と地下水涵養効果の評価.土 塞の物理特性, 108, 19-28.

嶋田 純・上野眞也編著（2016）持続可能な地下 水利用に向けた挑戦一地下水先進地域熊本から の発信一. 熊本大学政創研叢書 9 , 誠文堂, $294 \mathrm{p}$.

嶋田 純（2018）熊本地震による地域地下水へ の影響評価. サントリー天然水の森フォーラム 2018, 14.

高本尚彦・嶋田 純 - 德永朋祥 (2016) 難透水性 湖底堆積物コアの間隙水を用いた霞ヶ浦の完新 世に打ける古水文状況の復元. 地下水学会誌, 58 (3), 273-288.

高本尚彦・嶋田 純 - 白石知成 (2017) 非定常地 下水流動解析による霞ヶ浦の完新世における古 水文環境の復元. 地下水学会誌, 59 (4), 325343.

辻村真貴（2008）マルチ・トレーサー手法による 
流域水・物質循環プロセスのモデル化に関する

研究. 科研費基盤研究 $\mathrm{C}$ 成果報告書, $109 \mathrm{p}$. 細野高啓 - 山田千聡 - 柴田智郎 - 田原康博 - 嶋田 純（2018）熊本地震による地下水位変化メ力 ニズム。 日本地球惑星科学連合 2018 年大会, AHW24-04.

森 和紀 (2017) 水文科学: 基礎科学としての水 文学. 日本水文科学会誌，47(1)，17-21.

山下一仁（2016）農業を魅力ある就業先とするた めに. 日本労働研究雑誌, 675, 33-46.

山本荘毅（1967）ハイドロロジーの創刊によせて. ハイドロロジー，1，1.

Ide, K., Hosono, T., Hossain, S. and Shimada, J. (2018) Estimating silicate weathering timescales from geochemical modeling and spring water residence time in the Kirishima volcanic area, southern Japan. Chemical Geology, 488, 44-55.

Nakaya, S., Yasumoto, J., Ha, P., Aoki, H., Ko- hara, F. Masuda, H. and Masuoka, K. (2018) Hydrochemical behavior of an underground dammed limestone aquifer in the subtropics. Hydrological Processes, 32, 3529-3546.

Shimada, J., Inoue, D., Satoh, S., Takamoto, N., Sueda, T., Hase, Y., Iwagami, S., Tsujimura, M., Ishitobi, T. and Taniguchi, M. (2007) Basin-wide groundwater flow study in a volcanic low permeability bedrock aquifer with coastal submarine groundwater discharge. IAHS publication, 312, 75-85.

Shimada, J., Ichiyanagi, K., Kagabu, M., Saita, S. and Mori, K. (2012) Effect of artificial recharge using abandoned rice paddies for the sustainable groundwater management in Kumamoto. In: Proceedings of the 2012 Congress, World Environmental and Water Resources Congress. Loucks, E. D. (Ed.), The American Society of Civil Engineers, 59-69. 